\title{
Tree Species Composition and Regeneration Status of Shitalpur Forest Beat under Chittagong North Forest Division, Bangladesh
}

\author{
Asadozzaman Nur, Rajasree Nandi, \\ Mohammed Jashimuddin, and Mohammed Akhter Hossain \\ Institute of Forestry and Environmental Sciences, University of Chittagong, Chittagong 4331, Bangladesh \\ Correspondence should be addressed to Rajasree Nandi; rajasree.nandi@gmail.com
}

Received 24 July 2016; Accepted 12 October 2016

Academic Editor: Junbao Yu

Copyright ( $) 2016$ Asadozzaman Nur et al. This is an open access article distributed under the Creative Commons Attribution License, which permits unrestricted use, distribution, and reproduction in any medium, provided the original work is properly cited.

Biodiversity erosion particularly in developing countries is a matter of great concern to the global ecological community. Species composition and regeneration indicate the health of forest. This study explored tree species composition and regeneration of natural hill forest of Shitalpur under Chittagong North Forest Division through 27 sample plots of $20 \mathrm{~m} \times 20 \mathrm{~m}$ for trees and $2 \mathrm{~m} \times 2 \mathrm{~m}$ for regeneration. A total of 47 tree species belonging to 29 families and 17 regenerating species belonging to 15 families were recorded. The tree stem density, basal area, and wood volume were $0.49 \mathrm{~m}^{2} / \mathrm{ha}, 1425 \mathrm{stem} / \mathrm{ha}$, and $189.9 \mathrm{~m}^{3} / \mathrm{ha}$, respectively. Mean regeneration was significantly higher in bottom hill (14374 seedlings/ha) compared to top hill ( 9671 seedlings/ha). Toona ciliata was highest (4444 seedlings/ha) at the bottom hill compared to other hill positions. The result shows that only $36 \%$ of the tree species (17 out of 47) are regenerating in the study area, meaning majority of the tree species (64\%) are not getting favorable conditions to regenerate. This might be due to absence of mature tree species as a result of overexploitation by local people. The findings may help in monitoring the species composition changes over time and adopting specific conservation programs for Shitalpur Forest.

\section{Introduction}

The total area of Bangladesh is 14,757 million hectares, of which forest lands account for almost 17.5\% (2.53 million ha). The total forest land includes classified and unclassified state lands, homestead forests, and tea and rubber gardens. Bangladesh has a rich biological heritage containing about 5700 species of angiosperms [1]. During last few decades, the whole natural forest structure of Bangladesh was negatively changed by both biotic and abiotic disturbances which ultimately affect the regeneration and population dynamics $[2,3]$. Many forces are responsible for forest degradation, collectively and individually. The trend of these forces is very complex. The major causes of forest degradation in Bangladesh are agricultural expansion, overextraction of wood and nonwood resources, infrastructure development, population growth, deforestation, settlement, urbanization, and inappropriate management practices [4-6]. The rapid loss and degradation of forests in Bangladesh have brought about an alarming rate of forest biodiversity depletion $[1,7]$.
Many plant and animal species widely distributed in the past have either become extinct or can only be found in some localized areas at very low population densities.

Forestry is an important sector in Bangladesh's economy, which contributes about $1.28 \%$ of the country's gross domestic product (GDP) [8]. The Chittagong Hill Tracts (CHT) in Bangladesh supports almost $80 \%$ of the country's total biodiversity [9] and is inhibited by people from 12 ethnic groups [10-16] who depend largely on forest commons to fulfill their basic subsistence requirements and cash income $[10,12,17]$. The wide variety of plants and animals of the hill forests has supported the livelihoods of the hill people including dwelling, food, clothing, health care, and festivals. For many centuries, the indigenous communities have managed the forests in a sustainable manner by keeping the rotation of their shifting cultivation long enough (1520 years) [17, 18]. Population pressure, overcropping, soil erosion, indiscriminate illegal logging in forest areas, lack of suitable land, shifting cultivation with shortened fallow period (3-4 years) $[7,15,17-20]$ result in falling yields and 
drastic loss of forest coverage leading to land degradation [21]. Several studies were carried out in the recent years to investigate the plant diversity and community structure status in Sitapahar reserve forest of Chittagong Hill Tracts (South) Forest Division, Chunati Wildlife Sanctuary, Ukhiya natural forests of Cox's-Bazar Forest Division, and Bamu reserve forests of Cox's Bazar. But information on species composition in Shitalpur Forest Beat was not available previously. Moreover, information on floristic composition and their quantitative structure and diversity is vital for understanding the functioning and dynamics of forest ecosystems [22]. Therefore, the main objective of the study was to investigate the vegetative composition and species diversity and also the status of natural regeneration on different hill slopes in Shitalpur Forest Beat under Kumira Range in Chittagong North Forest Division.

\section{Materials and Methods}

2.1. Selection of the Study Area. The study was conducted at Shitalpur Forest Beat under Kumira Range of Chittagong North Forest Division. It is situated at the northwestern part of Chittagong district, between $22^{\circ} 27^{\prime} 31^{\prime \prime} \mathrm{N}$ and $22^{\circ} 27^{\prime} 31^{\prime \prime} \mathrm{N}$ latitude and $91^{\circ} 47^{\prime} 02^{\prime \prime}$ and $91^{\circ} 46^{\prime} 07^{\prime \prime} \mathrm{E}$ longitude. The total area of the beat was 1962 hectares of which $41 \%$ comprised protected forest and 37\% vested forest and the remaining other forest. A small area of around 100 ha under Shitalpur Forest Beat situated adjacent to western boundary of Chittagong University campus was first selected for this study. Topographically, the study area comprised mostly hills and valleys. The total area sampled under this study was 1.08 hectares.

The study was based on primary data collection regarding the systematic survey on the status, structure, composition, and diversity of trees of the study area and the effects of topography on natural regeneration. Necessary information was collected through extensive field observation of the area. The study was based on field data collection through physical measurement in the field and review of relevant literature on similar previous studies based on species composition in Chittagong and Chittagong Hill Tracts. The following steps had been followed for the preparation of this paper.

2.2. Data Collection and Analysis. At first a reconnaissance survey was conducted to become familiar with the study sites and the relevant information was collected from Nondonkanon, Chittagong Range office, and Shitalpur Beat Office. To have an idea of species composition of the whole study area, a number of field visits were conducted at the advent of the field work. Two transect walks (one from North to South and other from East to West) across the study area was made with the help of Field Assistant as per [7]. The aim of the walk was to be familiar with the vegetation in order to get a general idea of the site, topography, species composition, and natural regeneration of the study area.

The Shannon-Wiener index [23] and Simpson's index [24] were used as diversity indices. Statistical package SPSS 13.0 was used to conduct the statistical analysis under this study.
The basal area per tree and volume per tree were calculated by the formula given by Chaturvedi and Khanna [25]:

$$
\text { Basal area per tree }=3.14 \times \frac{D^{2}}{4},
$$

where $D$ is diameter at breast height in meter;

$$
\text { Volume }(V)=\text { Basal area } \times H \text {, }
$$

where $H$ is total height in meter.

Then, from the basal area and volume of individual tree, total basal area of each species was calculated and then converted to the basal area per hectare and volume per hectare for each species.

2.3. Sampling Design. The sample plots were selected by purposive sampling method. At first, three hills situating at a distance of about $500 \mathrm{~m}$ from each other were selected intentionally from the study area. In each of the selected hills, 9 sample plots (3 plots on each topography, namely, top hill, middle hill, and bottom hill; about $100 \mathrm{~m}$ apart from each other) of sizes $20 \mathrm{~m} \times 20 \mathrm{~m}$ were demarcated for final study. In this way, a total of 27 sample plots were demarcated for data collection. For regeneration study, $2 \mathrm{~m} \times 2 \mathrm{~m}$ subplots were taken at the corner point of each of the 27 sample plots and thus a total of 108 regeneration subplots were studied from the study area. All the sample plots and subplots were well demarcated, their corners were marked with pegs, and then all the tree species including seedlings and saplings in each plot were identified and recorded.

\section{Results}

3.1. Tree Species Composition. In the study area, a total of 47 different tree species comprising 29 families were recorded. Among the families, Moraceae (5 species) comprises the highest number of species followed by Apocynaceae (3 species), Euphorbiaceae (3 species), Leguminosae (3 species), and Verbenaceae (3 species) and the rest of the families comprise one or two species (Table 1).

3.2. Structural Composition of Tree Species at Different Hill Position. The study revealed that the tree basal area was found higher in top hill $\left(0.89 \mathrm{~m}^{2} / \mathrm{ha}\right)$ followed by bottom hill $\left(0.36 \mathrm{~m}^{2} / \mathrm{ha}\right)$ and middle hill $\left(0.22 \mathrm{~m}^{2} / \mathrm{ha}\right)$ with an average basal area of $0.49 \mathrm{~m}^{2} /$ ha in the study area. However, middle hill showed highest tree density (1566 stems/ha) compared to bottom hill (1466 stems/ha) and top hill (1244 stems/ha) positions with an average of 1425 stems/ha in the study area (Table 2). Tree volume was also found higher in the bottom hill $\left(248.79 \mathrm{~m}^{3} / \mathrm{ha}\right)$ followed by top hill $\left(201.02 \mathrm{~m}^{3} / \mathrm{ha}\right)$ and middle hill (120.02 $\left.\mathrm{m}^{3} / \mathrm{ha}\right)$, having an average volume of $189.9\left(\mathrm{~m}^{3} / \mathrm{ha}\right)$ in the study area (Table 2$)$.

3.3. Species Diversity Analysis. Diversity index was calculated for tree species. The Shannon-Wiener index value was found 3.49 in case of tree species which indicates that the plant diversity of the study area is less diverse whereas Simpson's 
TABLE 1: List of tree species with their families and stems/ha in the study area.

\begin{tabular}{|c|c|c|}
\hline Sl. number & Name of family & Scientific name \\
\hline 1 & Anacardiaceae & $\begin{array}{l}\text { Lannea coromandelica } \\
\text { Spondias pinnata }\end{array}$ \\
\hline 2 & Apocynaceae & $\begin{array}{c}\text { Brownlowia elata } \\
\text { Alstonia scholaris } \\
\text { Holarrhena antidysenterica }\end{array}$ \\
\hline 3 & Bignoniaceae & Stereospermum chelonoides \\
\hline 4 & Bombacaceae & Bombax ceiba \\
\hline 5 & Burseraceae & Bursera serrata \\
\hline 6 & Caesalpiniaceae & Cassia fistula \\
\hline 7 & Combretaceae & $\begin{array}{l}\text { Terminalia bellirica } \\
\text { Terminalia catappa }\end{array}$ \\
\hline 8 & Cycadaceae & Cycas pectinata \\
\hline 9 & Dilleniaceae & $\begin{array}{c}\text { Dillenia pentagyna } \\
\text { Dillenia indica }\end{array}$ \\
\hline 10 & Ebenaceae & Diospyros toposia \\
\hline 11 & Euphorbiaceae & $\begin{array}{c}\text { Macaranga denticulata } \\
\text { Aporusa oblonga } \\
\text { Phyllanthus emblica }\end{array}$ \\
\hline 12 & Fabaceae & $\begin{array}{l}\text { Erythrina stricta } \\
\text { Derris robusta }\end{array}$ \\
\hline 13 & Fagaceae & Castanopsis tribuloides \\
\hline 14 & Flacourtiaceae & Flacourtia jangomas \\
\hline 15 & Lauraceae & $\begin{array}{c}\text { Beilschmiedia Pseudomicrocarpa } \\
\text { Litsea monopetala }\end{array}$ \\
\hline 16 & Leguminosae & $\begin{array}{c}\text { Albizia procera } \\
\text { Erythrina variegate } \\
\text { Albizia chinensis }\end{array}$ \\
\hline 17 & Lythraceae & Lagerstroemia speciosa \\
\hline 18 & Meliaceae & Toona ciliata \\
\hline 19 & Moraceae & $\begin{array}{c}\text { Ficus hispida } \\
\text { Ficus pyriformis } \\
\text { Ficus racemosa } \\
\text { Artocarpus lacucha } \\
\text { Artocarpus chaplasha }\end{array}$ \\
\hline 20 & Musaceae & Musa textiles \\
\hline 21 & Myrtaceae & Syzygium fruticosum \\
\hline 22 & Papilionaceae & Derris trifoliate \\
\hline 23 & Rutaceae & Feronia limonia \\
\hline 24 & Sapindaceae & Erioglossum edule \\
\hline 25 & Sterculiaceae & $\begin{array}{c}\text { Abroma augusta } \\
\text { Pterospermum canescens }\end{array}$ \\
\hline 26 & Tiliaceae & Microcos paniculata \\
\hline 27 & Vaticeae & Vitis glabrata \\
\hline 28 & Verbenaceae & $\begin{array}{c}\text { Callicarpa macrophylla } \\
\text { Vitex peduncularis } \\
\text { Gmelina arborea }\end{array}$ \\
\hline 29 & Rubiaceae & Anthocephalus chinensis \\
\hline
\end{tabular}

index value is 0.04 which represents that the area is not dominated by only a single species; it is dominated by few tree species (Table 3).

3.4. Structural Composition of Naturally Regenerated Seedling. In the study area, a total of 17 species belonging to 15
TABLE 2: Growth performance of tree species in different hill position of the study area.

\begin{tabular}{lcccc}
\hline Variables & Top hill & Middle hill & Bottom hill & Average \\
\hline $\begin{array}{l}\text { Basal area } \\
\left(\mathrm{m}^{2} / \mathrm{ha}\right)\end{array}$ & 0.888889 & 0.222222 & 0.361111 & 0.49 \\
$\begin{array}{l}\text { Tree density } \\
(\text { stems } / \text { ha })\end{array}$ & 1244 & 1566 & 1466 & 1425.33 \\
$\begin{array}{l}\text { Tree volume } \\
\left(\mathrm{m}^{3} / \mathrm{ha}\right)\end{array}$ & 201.02 & 120.02 & 248.79 & 189.9 \\
\hline
\end{tabular}

TABLE 3: Important biodiversity indices calculated for the study area.

\begin{tabular}{lc}
\hline Index & Value \\
\hline Shannon-Wiener index & 3.49 \\
Simpson's index & 0.04 \\
\hline
\end{tabular}

families were found to regenerate naturally at different hill positions (Table 4). Among the families, only Euphorbiaceae and Moraceae showed more than one species to regenerate. All these regenerating species were observed at their tree phases.

3.5. Quantitative Structure of Naturally Regenerated Seedling at Different Hill Position. The regeneration study shows that the number of regenerating seedlings was found higher for Bursera serrata (2292 seedlings/ha) at the top hill fol lowed by Stereospermum chelonoides (1250 seedlings/ha), Phyllanthus emblica (972 seedlings/ha), Dillenia pentagyna (917 seedlings/ha), and Macaranga denticulata (833 seedlings/ha) (Table 4). At the middle hill, Ficus hispida showed higher number of regenerating seedlings (2917 seedlings/ha) followed by Bursera serrata (1575 seedlings/ha) and Ficus racemosa (1319 seedlings/ha). On the other hand, at the bottom hill, Toona ciliata showed higher number of regeneration seedlings (4444 seedlings/ha) followed by Bursera serrata (2708 seedlings/ha), Syzygium fruticosum (1736 seedlings/ha), and Stereospermum chelonoides (1458 seedlings/ha). On average, Bursera serrata (2192 seedlings/ha) showed highest regeneration followed by Toona ciliata (1481 seedlings/ha), Stereospermum chelonoides (1253 seedlings/ha), Ficus hispida (1181 seedlings/ha), and Macaranga denticulata (1088 seedlings/ha) compared to other species irrespective of hill positions. However, Toona ciliata showed remarkably higher regeneration at the bottom hill position compared to other regenerating species which might be due to favorable condition prevailing at the study area for this species. It was also observed that number of species at the regeneration stage was lowest at the bottom hill position (8 species) compared to top hill (11 species) and middle hill (11 species). Regeneration of seedlings per hectare was found to have occurred more in bottom hill (14374 seedlings/ha) compared to middle hill (13097 seedlings/ha) and top hill (9671 seedlings/ha) showing an average regeneration of 12381 seedlings/ha. Again, among the tree species, Toona ciliata (4444 seedlings/ha), Beilschmiedia psudomicrocarpa (903 seedlings/ha), and Microcos paniculata (1181 seedlings/ha) were found regenerating at the bottom hill, Musa textiles (1313 seedlings/ha), Abroma augusta 
TABLE 4: List of naturally regenerated seedlings with their families in the study area.

\begin{tabular}{lccc}
\hline Sl. number & Family & Scientific name & Local name \\
\hline 1 & Apocynaceae & Kolarrhena antidysenterica & Kuruch \\
2 & Bignoniaceae & Stereospermum chelonoides & Gutgutia \\
3 & Burseraceae & Bursera serrata & Bohera \\
4 & Combretaceae & Terminalia bellirica & Hargaza \\
5 & Dilleniaceae & Dillenia pentagyna & Amloki \\
6 & Euphorbiaceae & Phyllanthus emblica & Bura \\
7 & Lauraceae & Macaranga denticulate & Tuangiri \\
8 & Leguminosae & Beilschmiedia Pseudomicrocarpa & Madar \\
9 & Meliaceae & Erythrina variegate & Toon \\
10 & Moraceae & Toona ciliata & Joigga dumur \\
11 & Ficus racemosa & Dumur \\
12 & Musaceae & Ficus hispida & Pahari kola \\
13 & Myrtaceae & Musa textiles & Puti Jam \\
14 & Sterculiaceae & Ulat kombol \\
15 & Tiliaceae & Abroma augusta & Achargula \\
& Verbenaceae & Microcos paniculata & Bormala \\
\hline
\end{tabular}

TABLE 5: Quantitative structure of naturally regenerated seedlings found in the study area.

\begin{tabular}{|c|c|c|c|c|c|}
\hline \multirow{2}{*}{ Sl. number } & \multirow{2}{*}{ Scientific name } & \multicolumn{4}{|c|}{ Regeneration density (seedlings/ha) } \\
\hline & & Top hill & Middle hill & Bottom hill & Average \\
\hline 1 & Macaranga denticulate & 833 & 1111 & 1319 & 1088 \\
\hline 2 & Ficus hispida & 625 & 2917 & - & 1181 \\
\hline 3 & Phyllanthus emblica & 972 & - & - & 324 \\
\hline 4 & Callicarpa macrophylla & 644 & 972 & 625 & 747 \\
\hline 5 & Dillenia pentagyna & 917 & 833 & - & 583 \\
\hline 6 & Bursera serrata & 2292 & 1575 & 2708 & 2192 \\
\hline 7 & Stereospermum chelonoides & 1250 & 1050 & 1458 & 1253 \\
\hline 8 & Terminalia bellirica & 486 & 788 & - & 425 \\
\hline 9 & Ficus racemosa & 541 & 1319 & - & 620 \\
\hline 10 & Holarrhena antidysenterica & 764 & - & - & 255 \\
\hline 11 & Musa textiles & - & 1313 & - & 438 \\
\hline 12 & Syzygium fruticosum & 347 & - & 1736 & 694 \\
\hline 13 & Erythrina variegate & - & 694 & - & 231 \\
\hline 14 & Abroma augusta & - & 525 & - & 175 \\
\hline 15 & Toona ciliata & - & - & 4444 & 1481 \\
\hline 16 & Beilschmiedia pseudomicrocarpa & - & - & 903 & 301 \\
\hline 17 & Microcos paniculata & - & - & 1181 & 394 \\
\hline Total & & 9671 & 13097 & 14374 & 12381 \\
\hline
\end{tabular}

(694 seedlings/ha), and Erythrina variegata (525 seedlings/ha) at the middle hill, and Phyllanthus emblica (972 seedlings/ha) and Holarrhena antidysenterica (764 seedlings/ha) at the top hill positions only (Table 5).

3.6. Changes in Species Composition among Tree Phases. Study result also reveals that tree species diversity (Tables 1 and 2) is higher than the regenerating species diversity (Tables 4 and 5). Among 47 tree species, growing in the study area, only 17 tree species (36\%) were found regenerating and the remaining 30 tree species (64\%) did not show any regeneration at the study (Table 6). This may be due to the anthropogenic disturbances that cause disruption of forest structure and changes in species composition ultimately leading to reduction of tree species richness and abundance.

3.7. Effects of Hill Position on Natural Regeneration. From the study it was observed that the highest amount of regeneration was found in the bottom and lowest amount of regeneration was found in the top hill (Table 7). Significant difference was observed between top hill and bottom hill positions. 
TABLE 6: List of species that did not show regeneration at the study area.

\begin{tabular}{|c|c|c|}
\hline SI. number & Family & Scientific name \\
\hline 1 & Anacardiaceae & $\begin{array}{l}\text { Lannea coromandelica } \\
\text { Spondias pinnata }\end{array}$ \\
\hline 2 & Apocynaceae & $\begin{array}{l}\text { Brownlowia elata } \\
\text { Alstonia scholaris }\end{array}$ \\
\hline 3 & Bombacaceae & Bombax ceiba \\
\hline 4 & Caesalpiniaceae & Cassia fistula \\
\hline 5 & Combretaceae & Terminalia catappa \\
\hline 6 & Cycadaceae & Cycas pectinata \\
\hline 7 & Dilleniaceae & Dillenia indica \\
\hline 8 & Ebenaceae & Diospyros toposia \\
\hline 9 & Fabaceae & $\begin{array}{c}\text { Erythrina stricta } \\
\text { Derris robusta }\end{array}$ \\
\hline 10 & Fagaceae & Castanopsis tribuloides \\
\hline 11 & Flacourtiaceae & Flacourtia jangomas \\
\hline 12 & Rubiaceae & Anthocephalus chinensis \\
\hline 13 & Lauraceae & Litsea monopetala \\
\hline 14 & Leguminosae & $\begin{array}{c}\text { Albizia procera } \\
\text { Albizia chinensis }\end{array}$ \\
\hline 15 & Lythraceae & Lagerstroemia speciosa \\
\hline 16 & Meliaceae & Ficus pyriformis \\
\hline 17 & Moraceae & $\begin{array}{l}\text { Artocarpus lacucha } \\
\text { Artocarpus chaplasha }\end{array}$ \\
\hline 18 & Papilionaceae & Derris trifoliate \\
\hline 19 & Rutaceae & Feronia limonia \\
\hline 20 & Sapindaceae & Erioglossum edule \\
\hline 21 & Sterculiaceae & $\begin{array}{c}\text { Pterospermum canescens } \\
\text { Abroma augusta }\end{array}$ \\
\hline 22 & Vaticeae & Vitis glabrata \\
\hline 23 & Verbenaceae & $\begin{array}{l}\text { Vitex peduncularis } \\
\text { Gmelina arborea }\end{array}$ \\
\hline
\end{tabular}

TABLE 7: Regeneration of species in different position of the hill in Shitalpur Forest.

\begin{tabular}{lc}
\hline Hill position & Mean amount of regeneration (seedlings/ha) \\
\hline Top & $9671^{\mathrm{b}}$ \\
Middle & $13097^{\mathrm{ab}}$ \\
Bottom & $14374^{\mathrm{a}}$ \\
\hline
\end{tabular}

Note: ${ }^{\mathrm{a}, \mathrm{b}, \mathrm{ab}}$ different superscripts in a column indicate the least significant differences at $<0.05$.

However, middle hill did not show any significant difference in regeneration compared to top and bottom hill positions.

\section{Discussion}

Species composition, density, and regeneration status can be considered important factors to judge the status of a forest. A total of 47 different tree species comprising 29 families were recorded from the study area of which about $62 \%$ of the families are represented by only one species, $21 \%$ of the families by two species, $14 \%$ of the families by three species, and only $3 \%$ of the families by more than three species. The findings of the present study showed better species composition compared to a study [26] conducted by Ahmed and Haque where 38 tree species were identified whereas other studies [2731] found better species composition than the present study showing 64 species, 85 tree species, 92 tree species, 163 species, and 62 tree species, respectively. Moraceae was the dominant family (5 species) with naturally growing fruit species, like Artocarpus chaplasha, Artocarpus lacucha, Ficus hispida, Ficus pyriformis, and Ficus racemosa that provide food and shelter to wildlife species. The dominance of this family might be due to the excellent dispersal capacities of their seeds, pollen grains, and so forth by wind, water, birds, mammals, and humans. Similar studies by Newaz [32] also recorded maximum number of species from the family Leguminosae followed by Moraceae and Myrtaceae, and Das [33] documented that Leguminosae contains higher number of species than Bignoniaceae followed by Moraceae, Sapindaceae, and Myrtaceae and some other families. This suggests that Moraceae is a more or less common family in the hill ecosystems.

The study reveals a degraded forest status with less tree density (1425 stems/ha) and species regeneration (12381 seedlings/ha) compared to some previous study conducted in different parts of greater Chittagong region $[27,33,34]$. The reason behind less tree density and species regeneration might be due to the degraded environmental condition at the study area and at the same time overexploitation by the local people as they collect bigger trees for their own consumption and extra income. This way local people are also disturbing the forest floor and contributing greatly towards biodiversity loss. However, the present study shows better tree density (1425 stems/ha) in comparison to 381 stems/ha in Sitapahar reserve forest of Chittagong Hill Tracts (South) Forest Division [35], 459 stems/ha in Chunati WS [29], 257 stems/ha in Ukhiya natural forests of Cox's-Bazar Forest Division [26], 369 stems/ha in Bamu reserve forests of Cox's Bazar [28], and 384 stems/ha in a Dipterocarpus forest in Bangladesh [36]. Middle hill showed highest tree density (1566 stems/ha) compared to bottom hill (1466 stems/ha) and top hill (1244 stems/ha) positions. Study conducted by [37] also observed highest density at mid altitude site compared to lower and lowest altitude site although [38] reported significantly negative correlation of density and species richness with altitude and slope. Bursera serrata, Toona ciliata, Stereospermum chelonoides, Ficus hispida, Macaranga denticulata, Callicarpa macrophylla, and Syzygium fruticosum were found dominating (higher numbers of seedlings/ha) among the regenerated tree species.

The Shannon-Wiener index (3.49) represents less plant diversity of the study area whereas Simpson's index (0.04) depicts fewer numbers of species growing in the study area (Table 3). Nandi and Vacik [39] also observed less species diversity with trees under $\mathrm{dbh}>6 \mathrm{~cm}$ category at the Sitakunda Botanical Garden and Eco-Park, Chittagong, which is adjoining the study area. Though Sitakunda Botanical Garden and Eco-Park, once under the jurisdiction of Shitalpur Forest Beat, is managed as a special protected area 
for more than 15 years, the species diversity is still showing a meager value. This means that the anthropogenic disturbance may be the major cause of deforestation and forest degradation leading to less species diversity surrounding the study area. The same may also be true for the study area.

Our result indicates that Bursera serrata possess the highest number of seedlings per ha at the top hill followed by Stereospermum chelonoides, Phyllanthus emblica, Dillenia pentagyna, and Macaranga denticulata. While [32] found that top and middle hill were dominated by Stereospermum chelonoides, the valley was dominated by Ficus auriculata. So it is seen that Stereospermum chelonoides species is a common species at the secondary forest of Chittagong Forest Division. Moreover, regeneration of species was found to have occurred more in bottom hill and middle hill compared to top hill in this study area whereas [40] showed denser regeneration in nearly leveled hill tops and gentle slopes and moderately dense generation in medium slopes at the Sitakunda Botanical Garden and Eco-Park, Chittagong, Bangladesh. Study [33] also found highest seedling/ha at middle hill followed by top hill and bottom hill. We did find significant difference between the top hill and bottom hill position in terms of regeneration.

Change in species composition across mature and regenerating tree phases was observed at the study area. In this study, we found species without regenerating phases which is example of discontinuous population structures. Most of the tree species were absent at their regeneration stage at the study area. Only $36 \%$ of the tree species (17 out of 47) are regenerating in the study area, meaning majority of the tree species $(64 \%)$ are not getting favorable conditions to regenerate. Such example was found in [41]. The size class structures of trees indicate the probability of species persistence into the future; this information is very valuable in the design of management strategies aiming to improve stand structure and species diversity. Changes in species composition and recruitment of new species in different vegetation types are indicative of future species composition in changing environments [41].

\section{Conclusion}

The study revealed that Shitalpur Forest Beat is under threat of overextraction and illegal cutting which in the future may reduce both tree density and diversity drastically. Such detrimental interferences must be stopped immediately; otherwise this will reduce natural forest restoration capacity. The ecologically important plant species may be conserved through both in situ and ex situ conservation methods. It came out from the study that most of the people living near the forest area are poor, so they depend on forest for their livelihood. It has been observed that there exists a great demand and supply gap of fuel wood and other associated timber in this area, which ultimately increases the pressure of pilferage and illicit felling of trees from forest. To mitigate these problems and to maintain the complexity, species diversity, normal composition, and natural environment of Shitalpur Forest, large scale reforestation program can be carried out. However, adequate information and knowledge on the sustainable management of existing and potential resources in the study area is not available. So, there is a need to have a well-organized database on Shitalpur Forest resources for the purpose of forest protection and biodiversity conservation.

\section{Competing Interests}

The authors declare that they have no competing interests.

\section{Acknowledgments}

The authors would like to express gratitude to the Director of the Institute of Forestry and Environmental Sciences, University of Chittagong, Bangladesh, for his cooperation to conduct the study. The authors also express appreciation to field staff of Shitalpur Forest Beat for their cooperation during data collection.

\section{References}

[1] M. K. Hossain, "A review of forest biodiversity conservation in Bangladesh," Journal of Forestry and Environment, vol. 25, no. 1, pp. 102-110, 2001.

[2] P. B. Shafroth, J. C. Stromberg, and D. T. Patten, "Riparian vegetation response to altered disturbance and stress regimes," Ecological Applications, vol. 12, no. 1, pp. 107-123, 2002.

[3] C. Kwit and W. J. Platt, "Disturbance history influences regeneration of non-pioneer understory trees," Ecology, vol. 84, no. 10, pp. 2575-2581, 2003.

[4] M. A. Salam, T. Noguchi, and M. Koike, "The causes of forest cover loss in the Hill Forests in Bangladesh," GeoJournal, vol. 47, no. 4, pp. 539-549, 1999.

[5] M. Hasan and A. A. Alam, "Land degradation situation in bangladesh and role of agroforestry," Journal of Agriculture \& Rural Development, vol. 4, no. 1, pp. 19-25, 2008.

[6] M. K. Hossain, M. K. Alam, and Md. Danesh Miah, "Forest restoration and rehabilitation in Bangladesh," in Keep Asia Green Volume III South Asia, D. K. Lee, Ed., vol. 20-23 of IUFRO World Series, pp. 21-65, IUFRO, Vienna, Austria, 2008.

[7] M. A. Rahman, M. H. Rashid, and C. C. Wilcock, "Diversity, ecology, distribution and ethnobotany of the apocynaceae of Bangladesh," Bangladesh Journal of Plant Taxonomy, vol. 7, pp. 57-76, 2000.

[8] BBS, 2012, http://www.bbs.gov.bd.

[9] A. Nishat and S. R. Biswas, "Community based restoration of degraded tropical hill forests: experiences from Krykhong para, Chittagong Hill Tracts, Bangladesh," Bulletin of the National Institute of Ecology, India, vol. 16, pp. 1-11, 2005.

[10] G. Rasul, "Political ecology of the degradation of forest commons in the Chittagong Hill Tracts of Bangladesh," Environmental Conservation, vol. 34, no. 2, pp. 153-163, 2007.

[11] G. B. Thapa and G. Rasul, "Implications of changing national policies on land use in the Chittagong Hill Tracts of Bangladesh," Journal of Environmental Management, vol. 81, no. 4, pp. 441-453, 2006.

[12] M. D. Miah and M. S. H. Chowdhury, “Traditional forest utilization practice by the Mro tribe in the Bandarban region, Bangladesh," Swiss Forestry Journal, vol. 155, no. 3-4, pp. 65-70, 2004. 
[13] M. D. Miah and M. S. H. Chowdhury, "Indigenous healthcare practice through medicinal plants from forests by the Mro tribe in Bandarban region, Bangladesh," Indilinga, vol. 2, no. 2, pp. 59-74, 2003.

[14] W. Van Schendel, W. Mey, and A. K. Dewan, The Chittagong Hill Tracts: Living in a Boarderland, The University Press, Dhaka, Bangladesh, 2001.

[15] R. C. K. Roy, Land Rights of the Indigenous Peoples of the Chittagong Hill Tracts, Bangladesh, International Work Group for Indigenous Affairs (IWGIA), Copenhagen, Denmark, 2000.

[16] J. Nasreen and M. Togawa, "Politics of development: 'PahariBengali' discourse in the Chittagong Hill Tracts," Journal of International Development and Cooperation, vol. 9, pp. 97-112, 2002.

[17] G. Rasul and G. B. Thapa, "Shifting cultivation in the mountains of South and Southeast Asia: regional patterns and factors influencing the change," Land Degradation and Development, vol. 14, no. 5, pp. 495-508, 2003.

[18] S. Tiwari, Chittagong Hill Tracts: A Preliminary Study on Gender and Natural Resource Management, IDRC, Ottawa, Canada, 2003.

[19] R. D. Roy and S. Halim, "Valuing Village commons in forestry," Indigenous Perspectives, vol. 5, pp. 9-38, 2002.

[20] S. A. Rahman, M. F. Rahman, A. L. Codilan, and K. M. Farhana, "Analysis of the economic benefits from systematic improvements to shifting cultivation and its evolution towards stable continuous agroforestry in the upland of Eastern Bangladesh," International Forestry Review, vol. 9, no. 1, pp. 536-547, 2007.

[21] T. K. Nath and M. Inoue, "The upland settlement project of Bangladesh as a means of reducing land degradation and improving rural livelihoods," Small-Scale Forestry, vol. 7, no. 2, pp. 163-182, 2008.

[22] C. S. Reddy, B. Shilpa, A. Giriraj, K. N. Reddy, and K. T. Rao, "Structure and floristic composition of tree diversity in tropical dry deciduous forest of Eastern Ghats," Southern Andhra Pradesh, India. Asian Journal of Scientific Research, vol. 1, pp. 57-64, 2008.

[23] T. K. Nath, M. K. Hossain, and M. K. Alam, "Assessment of tree species diversity of Sitapahar Forest Reserve, Chittagong Hill Tracts (South) Forest Division, Bangladesh," Indian Forester, vol. 126, no. 1, pp. 16-21, 2000.

[24] E. H. Simpson, "Measurement of diversity," Nature, vol. 163, no. 4148, p. 688, 1949.

[25] A. N. Chaturvedi and S. L. Khanna, Forest Mensuration, International Book Distributors, Dehra Dun, India, 1982.

[26] G. U. Ahmed and S. M. S. Haque, "Percentage distribution of species and diameter class in natural forest of Bangladesh," University of Science Studies, vol. 17, no. 1, pp. 109-113, 1993.

[27] M. K. Hossain, M. Lutfor Rahman, A. T. M. Rafiqul Hoque, and M. Khairul Alam, "Comparative regeneration status in a natural forest and enrichment plantations of Chittagong (south) forest division, Bangladesh," Journal of Forestry Research, vol. 15, no. 4, pp. 255-260, 2004.

[28] M. K. Hossain, M. Hossain, and M. K. Alam, "Diversity and structural composition of trees in Bamu reserved forest of Cox's Bazar forest division, Bangladesh," Bangladesh Journal of Forest Science, vol. 25, no. 1, pp. 31-42, 1996.

[29] M. L. Rahman and M. K. Hossain, "Status of fodder and nonfodder tree species on Chunati Wildlife Sanctuary of Chittagong Forest Division, Bangladesh," International Journal of Forest Usufructs Management, vol. 4, no. 2, pp. 9-14, 2003.
[30] M. Jashimuddin and M. Inoue, "Management of village common forests in the Chittagong Hill Tracts of Bangladesh: Historical background and current issues in terms of sustainability," Open Journal of Forestry, vol. 2, no. 3, pp. 118-134, 2012.

[31] M. A. Motaleb and M. K. Hossain, "Tree species diversity in the Tankawati natural forest of Chittagong South Forest Division," Journal of Eco-Friendly Agriculture, vol. 4, no. 2, pp. 542-545, 2011.

[32] M. D. S. Newaz, "Diversity and composition of tree species regeneration in the secondary forests of chittagong, Bangladesh," Indian Forester, vol. 132, no. 11, pp. 1419-1428, 2006.

[33] K. Das, Effects of plantaion and topography on natural regeneration in Sitakund Eco-Park, Chittagong, Bangladesh [M.S. thesis], 2008.

[34] M. A. Hossain, M. K. Hossain, M. A. Salam, and S. Rahman, "Composition and diversity of tree species in dudhpukuriadhopachori wildlife sanctuary of chittagong (South) forest division, Bangladesh," Journal of Pharmaceutical, Chemical and Biological Sciences, vol. 4, no. 2, pp. 1447-1457, 2013.

[35] T. K. Nath, M. K. Hossain, and M. K. Alam, "Diversity and composition of trees in Sitapahar forest reserve of Chittagong Hill Tracts (South) Forest Division, Bangladesh," Annals of Forestry, vol. 6, no. 1, pp. 1-9, 1998.

[36] S. R. Biswas and K. Misbahuzzaman, "Tree species diversity and regeneration traits of the dominant species in a dipterocarp forest in Bangladesh: implications for conservation," International Journal of Biodiversity Science and Management, vol. 4, no. 2, pp. 81-91, 2008.

[37] S. Bharali, A. Paul, M. L. Khan, and B. Singha Lal, "Impact of altitude on population structure and regeneration status of two rhododendron species in a temperate broad leaved forest of arunachal Pradesh, India," International Journal of Ecosystem, vol. 2, no. 1, pp. 19-27, 2012.

[38] C. M. Sharma, S. Suyal, S. Gairola, and S. K. Ghildiyal, "Species richness and diversity along an altitudinal gradient in moist temperate forest of Garhwal Himalaya," Journal of American Science, vol. 5, no. 5, pp. 119-128, 2009.

[39] R. Nandi and H. Vacik, "Regeneration and tree species diversity of Sitakund Botanical Garden and Eco-park, Chittagong, Bangladesh," Journal of Mountain Science, vol. 11, no. 4, pp. $950-$ 958, 2014.

[40] K. Misbahuzzaman and M. J. Alam, "Ecological restoration of rainforest through aided natural regeneration in the denuded hills of Sitakund, Chittagong, Bangladesh," International Journal of Agriculture and Biology, vol. 8, no. 1, pp. 778-782, 2006.

[41] R. Jayakumar and K. K. N. Nair, "Species diversity and tree regeneration patterns in tropical forests of the Western Ghats, India," ISRN Ecology, vol. 2013, Article ID 890862, 14 pages, 2013. 

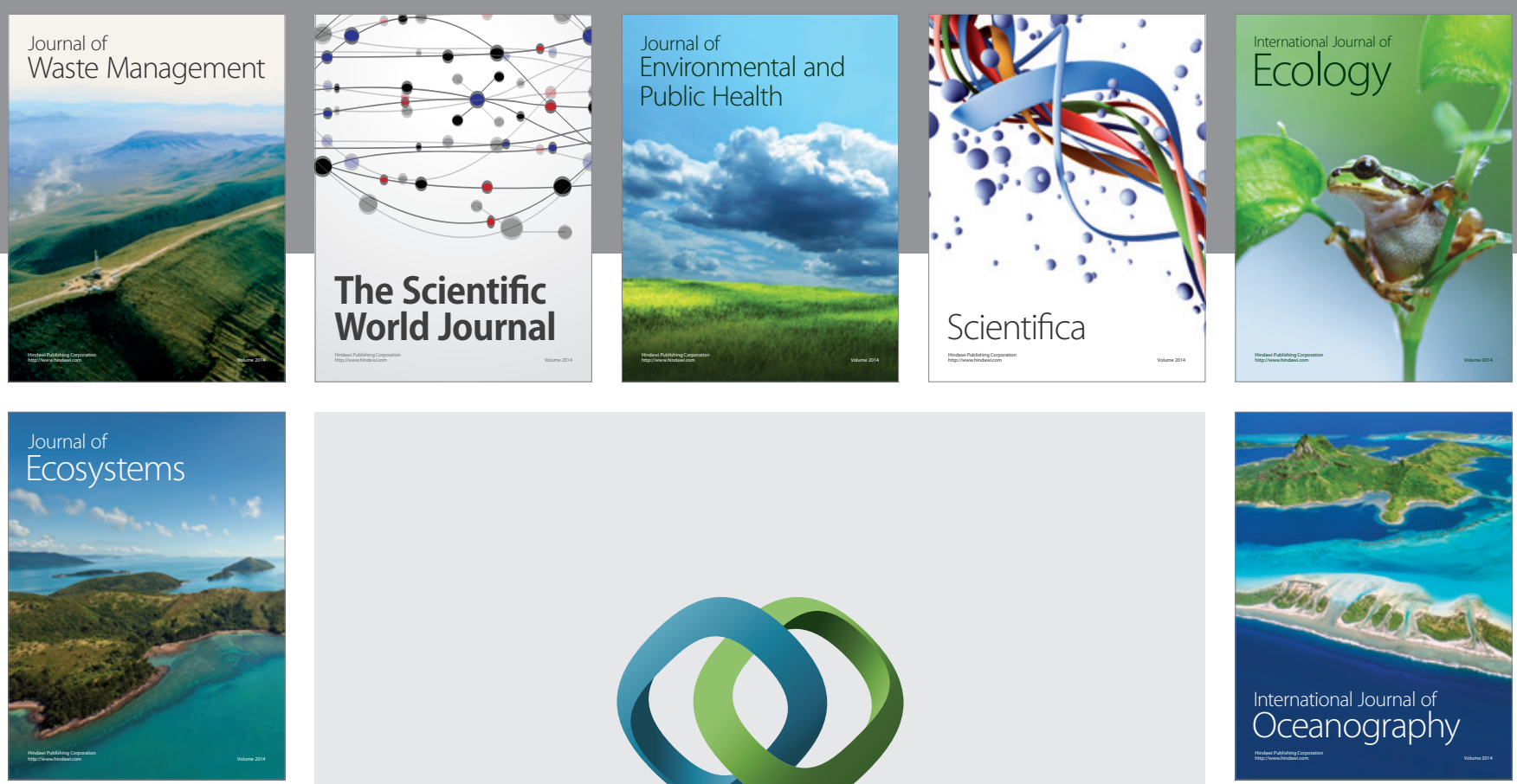

The Scientific World Journal
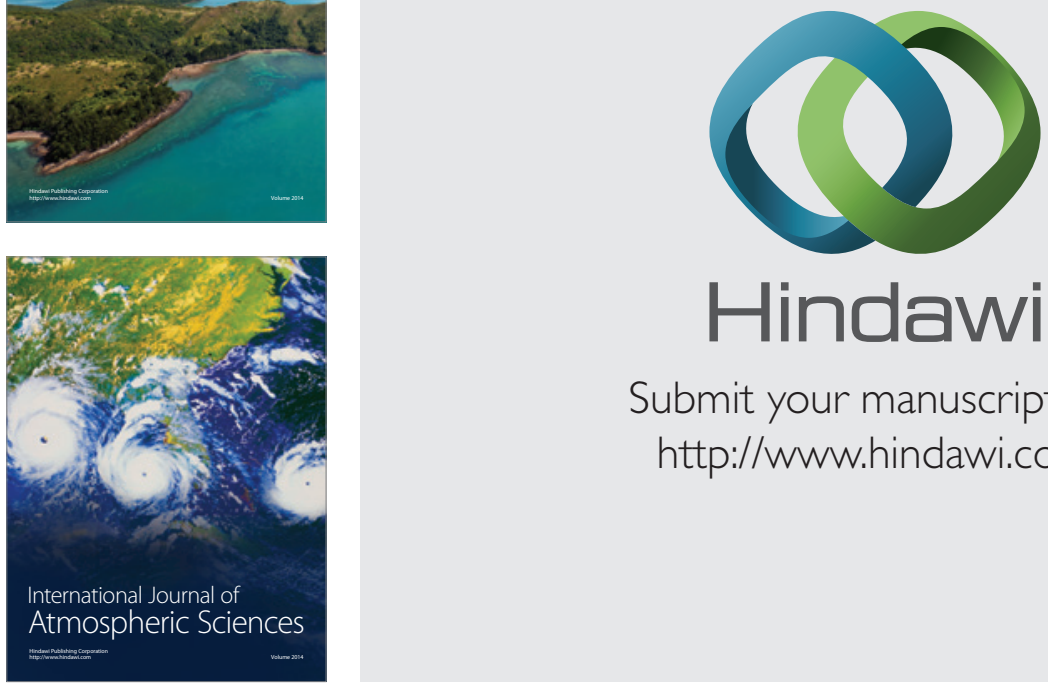

\section{Hindawi}

Submit your manuscripts at

http://www.hindawi.com
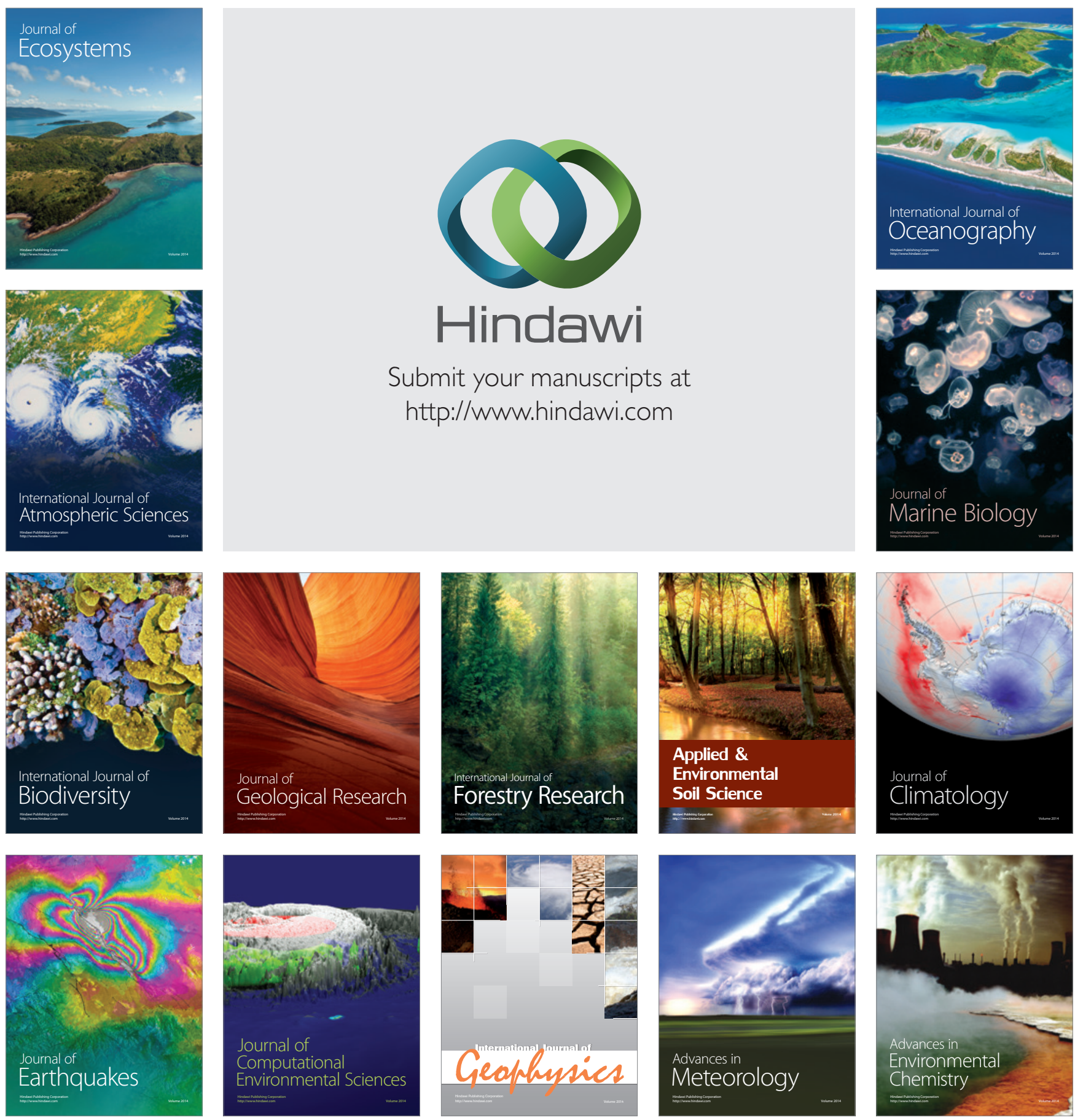